\title{
THE IMPLEMENTATION OF CORPORATE GOVERNANCE IN ISLAMIC BANKING IN INDONESIA BASED ON AAOIFI STANDARD
}

\author{
Rahma Yudi Astuti
}

Rahma67@unida.gontor.ac.id

\section{Fakultas Ekonomi dan Manajemen Universitas Darussalam Gontor}

\author{
Diterima : November 2020, Disetujui : Desember 2020, Dipublikasikan: Januari 2021
}

\begin{abstract}
This study aims to analyze the implementation of Corporate Governance in Islamic banking in Indonesia and the implementation of Corporate Governance in Islamic banking in Indonesia according to the standards of Corporate Governance by AAOIFI. This study used secondary data obtained from the annual report of Good Corporate Governance of Sharia Commercial Bank which has been published in 2019. The method used in this study is qualitative with the type of research is content analysis from the annual Good Corporate Governance report of Islamic bank in Indonesia. The results of this study indicate that the implementation of Corporate Governance at Sharia Commercial Banks in general have done good corporate governance which is marked with the result of self-assessment of every Sharia Commercial Bank which on average gets a good predicate. The results of research on the implementation of AAOIFI standards of Corporate Governance in general have applied some of the AAOIFI standards, but there is one standard AAOIFI that has not been applied by Sharia Commercial Banks other than Bank Muamalat. The standard that has not been applied is Internal Sharia Reviews which should be established in the policy.
\end{abstract}

Keywords: Islamic Banking, Corporate Governance, AAOIFI.

\section{ABSTRAK}

Penelitian ini bertujuan untuk menganalisis penerapan Tata Kelola pada perbankan syariah di Indonesia dan penerapan Tata Kelola pada perbankan syariah di Indonesia sesuai standar Tata Kelola Perusahaan oleh AAOIFI. Penelitian ini menggunakan data sekunder yang diperoleh dari laporan tahunan Good Corporate Governance Bank Umum Syariah yang telah diterbitkan pada tahun 2019. Metode yang digunakan dalam penelitian ini adalah kualitatif dengan jenis penelitian adalah analisis isi dari laporan tahunan Good Corporate Governance Syariah Islam. bank di Indonesia. Hasil penelitian ini menunjukkan bahwa penerapan Tata Kelola pada Bank Umum Syariah secara umum telah melaksanakan tata kelola perusahaan yang baik yang ditandai dengan hasil self assessment setiap Bank Umum Syariah yang rata-rata mendapat predikat baik. Hasil penelitian tentang penerapan standar AAOIFI Tata Kelola Perusahaan secara umum telah menerapkan beberapa standar AAOIFI, 
namun terdapat satu standar AAOIFI yang belum diterapkan oleh Bank Umum Syariah selain Bank Muamalat. Standar yang belum diterapkan adalah Internal Sharia Review yang harus ditetapkan dalam kebijakan.

Kata Kunci: Perbankan Syariah, Tata Kelola Perusahaan, AAOIFI.

\section{INTRODUCTION}

That the growth and development of Islamic banking are so rapidly lately markedby the increasing number of Islamic banking services network and the increasing diverse products leading to the implementation of Good Corporate Governance (GCG) in Islamic banking is becoming increasingly important. ${ }^{1}$ Good Corporate Governance (GCG) that serves to anticipate various risks, both financial risk and reputation, is also an important pillar that must be applied to create a Islamic bank that is superior and resilient. The Implementation of GCG in Islamic banks is important because Islamic banks are banks that use the principle of profit sharing (profit shared by the bank and customers). ${ }^{2}$

The implementation of Good Corporate Governance in Islamic banking in order to make Islamic bank become more shar' $i$ because its application in Islamic banking industry must fulfill sharia principles. Islamic banking operations must be strictly enforced based on sharia principles. On the other hand, the direction of development and regulation of Islamic banking is to ensure compliance with sharia principles in its operations by implementing fatwas issued by Dewan Syariah Nasional (DSN)\&Majelis Ulama Indonesia(MUI). ${ }^{3}$ The international standards specifically are established to realize Islamic Financial Institutions (IFI) which is totally fair, professional, and in accordance with sharia standard / principle. The majority of international Islamic banking adopts this standard and uses it as reference of compliance of Islamic bank to sharia standard / principle issued by AAOIFI institution.

AAOIFI is one of the prominent International standard-setting organizations for Islamic institutions. The AAOIFI sets compliance standards for institution that wish to gain access to the Islamic financial market and ensures that its participants also comply with the regulations set out within the domain of Islamic finance.

Hussainey stated that the compliance rate of Islamic Banks based on AAOIFI standards assessed in terms of Sharia Supervisory Board (SSB) is about 68\%, while the compliance rate for CSR is $27 \%$, and compliance rate for financial accountability is $73 \%$. The aggregate disclosure based on the three indices is $56 \%$. The analysis also shows that

\footnotetext{
${ }^{1}$ Penjelasan Atas Peraturan Bank Indonesian (PBI) No. 11/33/PBI/2009 Tentang Pelaksanaan Good Corporate Governance (GCG) Bagi Bank Umum Syariah (BUS) dan Unit Usaha Syariah (UUS) pada bagian Umum.

${ }^{2}$ Umer Chapra dan Habib Ahmed (2002). Corporate Governance In Islamic Financial Institutions (Jeddah: Islamic Research dan Islamic Institute, Islamic Development Bank), pp. 50-71.
}

${ }^{3}$ Akhmad Faozan (2013). Implementasi Good Corporate Governance Dan Peran Dewan Pengawas Syariah Di Bank Syariah. Jurnal Ekonomi Islam Vol VII, No. 1 
bank size, the existence of Sharia Auditing Department (SAD), the age of banks and Corporate Governance are the main determinants of compliance level. ${ }^{4}$

The author examines whether the existing Islamic banking in Indonesia has implemented the standards of Corporate Governance issued by AAOIFI. The author examines the implementations of Corporate Governance at the existing Sharia Commercial Bank in Indonesia using GCG annual report data published by each Sharia Commercial Bank in Indonesia.

Mardian stated that each Islamic bank has a different model in the fulfillment of sharia principles. ${ }^{5}$ This research is importantdue to the lack of research in Indonesia which examines the implementation of Corporate Governance based on AAOIFI standards. It also supports the practice of corporate governance in implementation of Islamic banking in accordance with the principles of sharia.

\section{LITERATURE REVIEW}

Islamic Banks is a part of Islamic Banking in Indonesia. The definition of Islamic banking is contained in Law No. 21 of 2008 Article 1 point 1 which states, ${ }^{6}$

"Islamicbanking is everything that concerns about Islamic bank and Islamic Business Unit, includes institutional, business activity, as well as the manner and process in carrying out its business activities."

Meanwhile, Sharia Principles which become the operational basis of Islamic Bank are described in Law No.21 of 2008 Article 1 point 12 which states, ${ }^{7}$

"Sharia principle is the principle of Islamic law in banking activities based on fatwas issued by institutions that have authority in the establishment of fatwa in the field of Sharia."

\section{Types of Islamic Bank in terms of its Function}

\section{Sharia Commercial Bank}

The definition of Sharia Commercial Bank is contained in Law No. 21 of 2008 Article 1 point 8 which states, ${ }^{8}$

"Sharia Commercial Bank is an Islamic Bank which in its activities provides services in the payment traffic."

\footnotetext{
${ }^{4}$ Sherif El-Halaby Khaled Hussainey, (2016). "Determinants of compliance with AAOIFI standards by Islamic Banks". International Journal of Islamic and Middle Eastern Finance and Management.

${ }^{5}$ Sepky Mardian. Studi Eksplorasi Pengungkapan Penerapan Prinsip Syariah di Bank Syariah. SEBI Islamic Economics \& Finance Journal Vol.04, No.1, Oktober 2011

${ }^{6}$ Undang-Undang Republik Indonesia Nomor 21 Tahun 2008 Tentang Perbankan Syariah Pasal 1 Ayat 1

${ }^{7}$ Ibid. Ayat 12

${ }^{8}$ Ibid. Ayat 8 
2. Islamic Business Unit

The definition of Islamic Business Unit is contained in Law No. 21 of 2008 Article 1 point 10 which states, ${ }^{9}$

"Islamic Business Unit, hereinafter referred to as UUS, is a work unit of the head office of a Conventional Commercial Bank functioning as the holding office of an office or unit conducting business based on Sharia Principles, or a work unit in a branch office of a Bank domiciled in a foreign country to carry out conventional business activities that function as the head office of the Sharia sub-branch office and / or sharia unit."

3. Rural Islamic Bank

The definition of Rural Islamic Bank is contained in Law No. 21 of 2008 Article 1 point 9 which states, ${ }^{10}$

"Rural Islamic Bank is an Islamic Bank which in its activities does not provide services in the payment traffic."

\section{Purpose and Function of Islamic Banking}

In its daily operations, Islamic Banking has a purpose and function that distinguishes it from Conventional Banking where the purpose of Islamic Banking is contained in Law No.21 of 2008 Article 3 namely, ${ }^{11}$

"Islamic Banking aims to support the implementation of National development in order to improve justice, togetherness, and equity of people's welfare".

\section{Activities of Islamic Banks}

To be able to achieve the goals and carry out its functions properly, then Islamic Bank performs operational activities as usual. Thus, it need to be made a series of guidelines in carrying out operational activities for the implementation of functions and achievement of goals can be achieved in accordance with expectations.

\section{Good Corporate Governance}

The term "Corporate Governance" was first introduced by the Cadbury Committee in 1992 in a report known as Cadbury Report. This report also marks a decisive turning point for Corporate Governance practices worldwide. In Cadbury Report, Corporate Governance is a system that serves to direct and control the organization. The Cadbury Report defines corporate governance as: ${ }^{12}$

"GCG is a principle that directs and controls the company to achieve a balance between the strength and authority of the company in providing accountability to its shareholders in particular, and stakeholders in general."

\footnotetext{
${ }^{9}$ Undang-Undang Republik Indonesia Nomor 21 Tahun 2008 Tentang Perbankan Syariah Pasal 1 Ayat 10

${ }^{10}$ Ibid. Ayat 9

${ }^{11}$ Ibid. Pasal 3

${ }^{12}$ The Committee on the Financial Aspects of Corporate Governance and Gee and Co. Ltd. 1992 


\section{The Principle of Good Corporate Governance}

A description of the principles of Corporate Governance is set forth in the Peraturan Otoritas Jasa Keuangan Number 30 / POJK.05 / 2014 Chapter 2 Article 2, paragraph 2, namely: ${ }^{13}$ "Transparency, Accountability, Responsibility,Independency, Equity and fairness"

\section{The Purpose of Good Corporate Governance}

According to Komite Nasional Kebijakan Governance(KNKG), Good Corporate Governance has six main objectives. The six main objectives are as follows: ${ }^{14}$

a. Encouraging the achievement of corporate sustainability

b. Encouraging the empowerment of functions and independence of each company's organs i.e. dean commissioners, directors and general meeting of shareholders (GMS).

c. Encouraging shareholders, members of the board of commissioners and members of the board of directors to make decisions and carry out their actions based on high moral values and compliance with laws and regulations.

d. Encouraging the emergence of awareness and corporate social responsibility to society and environmental sustainability, especially around the company.

e. Optimize corporate value for shareholders by watching other stakeholders.

f. Enhancing the competitiveness of companies both nationally and internationally

\section{Benefits of Good Corporate Governance}

With the implementation of Corporate Governance, the interests of investors are not only protected but also will be able to bring many benefits for the related companies and also other parties who have direct relationship or indirect with the company.

Various benefits gained with the implementation of Corporate Governance can be mentioned among others: ${ }^{15}$

a. With Good Corporate Governance decision-making process will take place better so that will result in optimal decision, can improve efficiency and create a healthier work culture.

b. Good Corporate Governance will enable it to be avoided or at least to minimize misuse of authority by the directors in managing the company.

c. The value of the company in the eyes of investors will increase as a result of their increased trust to the managers of the companies they invest

d. For shareholders, with the improvement of company performance by itself will also assess the value of their shares and the value of dividends they will receive.

e. Because in Good Corporate Governance practice, employees are placed as one of the stakeholders that should be well managed by the company.

\footnotetext{
${ }^{13}$ Peraturan Otoritas Jasa Keuangan Nomor 30/POJK.05/2014 Bab 2 Pasal 2 Ayat 2

${ }^{14}$ Komite Nasional Kebijakan Governance (KNKG). Pedoman Umum Good Corporate Governance Indonesia. 2006

${ }^{15}$ Azhar Maksum, "Tinjauan atas Good Corporate Governance di Indonesia". (Medan: Gelanggang Mahasiswa, Kampus USU, 17 Desember 2005), h.8.
} 
f. The consistent implementation of Corporate Governance will also improve the quality of the company's financial statements.

\section{Governance Standard by Accounting and Auditing Organization for Islamic Financial Institutions (AAOIFI)}

AAOIFI is responsible for developing and issuing standards for the Islamic finance industry international that supported by more than 200 institutional members of over 40 countries.

AAOIFI formulates and publishes accounting, auditing, governance, ethics and Islamic standards. As an independent international organization, AAOIFI'ssupported by institutional members (200 members from 40 countries) including the central bank, Islamic Finance Industry, and other participants from the International Islamic Banking and Finance Industry Worldwide. Currently, AAOIFI has published 88 standards including 26 accounting standards, 5 audit standards, 7 corporate governance standards, 2 code standards and 48 sharia standards.

\section{Corporate Social Responsibility Conduct and Disclosure for Islamic Financial Institutions}

a. Introduction

- The purpose of this Governance Standard for Islamic Financial Institutions (GSIFI) is to establish standards on the definition of Corporate Social Responsibility (CSR) for Islamic Financial Institutions, provide both mandatory and recommended standards to implement CSR in all aspects of the Islamic Financial Institutions (IFI) activities and provide guidance on disclosure of CSR information to the IFIs stakeholders.

b. Scope of this standard

- The principles of this standard are applicable to all IFIs, regardless of their legal form, country of incorporation or size. However, the specific rules and provisions of this standard for activities, compliance and disclosure are classified into mandatory and recommended sections. The mandatory sections are applicable to all IFIs regardless of their legal form, country of incorporation or size. The recommended sections are only applicable to IFIs which have the capacity, financial or otherwise, to carry out or comply with such activities.

\section{RESEARCH DESIGN}

This study aims to determine the extent of the implementation of corporate governance standards issued by AAOIFI at Sharia Commercial Bank in Indonesia on Good Corporate Governance Report issued every year. There are standards that become indicators in the implementation of corporate governance. Therefore, it takes a deep understanding to examine it. The approach used in this study is a qualitative approach. Qualitative method is a research procedure that produces descriptive data in the form of written or oral words of 
people and observed behavior. ${ }^{16}$ The reason of this research using qualitative approach is because in this research, the data produced in the form of descriptive data are obtained from the data in the form of writings, words and documents derived from sources or informants who studied and can be trusted.

Type of research used in this research is content analysis, which aims to find out the implementation of Corporate Governance in Islamic banking in Indonesia in terms of AAOIFI's Corporate Governance standard through the analysis of the annual Good Corporate Governance report of Islamic banking in Indonesia. The author used content analysis because the data to be researched requires descriptive explanation. ${ }^{17}$ Content analysis is a systematic technique for analyzing the content of messages and processing messages, or a tool for observing and analyzing the contents of open communication behavior of selected communicators. Content analysis can be used to analyze newspapers, websites, advertisements, interview records, as well as company annual reports. ${ }^{18}$

\section{RESULT AND DISCUSSION}

\section{Implementation of GCG in Islamic Banking in Indonesia}

Implementation of Good Corporate Governance (GCG) in Islamic banking industry must always be based on five basic principles. First, transparency which is an openness in expressing material and relevant information and openness in decision making process. Second, accountability is the clarity of the function and the implementation of bank organ liability so that its management runs effectively. Third, accountability is the suitability of bank management with prevailing laws and regulations and healthy bank management principles. Fourth, professionals are competent, able to act objectively, and from influence / pressure from any party (independent) and have high commitment to develop Islamic bank. Fifth, fairness is justice and equality in fulfilling the rights of stakeholders based on the agreement and the applicable legislation

The determination of the ranking of Good Corporate Governance is categorized into 5 (five) rankings, 1st, 2nd, 3rd, 4th, and 5th. The following is the determination of the Good Corporate Governance rating ranking as stipulated in Circular Letter of Financial Services Authority Number 10 / SEOJK .03 / 2014: ${ }^{19}$

\footnotetext{
${ }^{16}$ Lexy, J, Moleong. Metodologi Penelitian Kualitatif. Bandung: Remaja Rosdakarya, 1990.3

${ }^{17}$ Subiakto, H. (2004). Analisis Isi Media Metode dan Pemanfaatannya. Dalam B. Bungin (Penyunt.), Metodologi Penelitian Kualitatif (3 ed., hal. 133-143). Jakarta: PT RajaGrafindo Persada.

${ }^{18}$ Subiakto, H. (2004). Analisis Isi Media Metode dan Pemanfaatannya. Dalam B. Bungin (Penyunt.), Metodologi Penelitian Kualitatif (3 ed., hal. 133-143). Jakarta: PT RajaGrafindo Persada.

${ }^{19}$ Salinan Surat Edaran Otoritas Jasa Keuangan Nomor 10/SEOJK.03/2014 Tentang Penilaian Tingkat Kesehatan Bank Umum Syariah Dan Unit Usaha Syariah
} 
1. Ranked 1: Reflects the bank's management has done a generally very good GCG implementation.

2. Ranked 2: Reflects the bank's management has done a generally good GCG implementation.

3. Ranked 3: Reflects the bank's management has done a generally pretty good GCG implementation..

4. Ranked 4: Reflects the bank's management has done a generally poor implementation of GCG.

5. Ranked 5: Reflects the bank's management has done a generally unfavorable GCG implementation.

The implementation of good corporate governance on an ongoing basis is one of the keys to the company's survival in the face of competition. Good corporate governance is a tool to foster corporate integrity and maintain the trust of stakeholders.

In order to improve bank performance, protect the interests of stakeholders and improve compliance with prevailing laws and ethics values prevailing in the banking industry, Islamic banks must remain consistent in implementing GCG principally based on Bank Indonesia Regulation Number 11/33 / PBI / 2009 and Bank Indonesia Circular Letter no. $12 / 13 / \mathrm{DPbS}^{20}$

\section{Implementation of GCG in Islamic banking in Indonesia based on AAOIFI Standard}

Every year sharia commercial banks issue GCG Reports that are accessible through their official website, therefore the following will be explained on the results of GCG report analysis on the appraisal of AAOIFI standards implementation.

\section{Sharia Supervisory Board: Appointment, Composition and Report}

The Supervisory Board is a body that ensures that all guidelines and operational implementation of the bank meet Sharia principles. The following table results of GCG report analysis on the implementation of AAOIFI standard no 1:

The first point: Members of the Sharia Supervisory Board should be independent. The results of the analysis stated that every sharia bank has revealed that their Sharia Supervisory Board is independent. This is in accordance with the provisions of Bank Indonesia concerning the implementation of GCG, that the Sharia Supervisory Board is obligated to disclose multiple positions as a member of the Sharia Supervisory Board in other Islamic financial institutions.

The second point: the appointment of members of the Sharia Supervisory Board is conducted by the shareholders of Islamic finance institutions on the recommendation of the board of directors. The results of the analysis stated that in the case of appointment of Sharia Supervisory Board members to sharia commercial banks, many of them are recommended directly by the National Sharia Council of the Indonesian Ulema Council (DSN-MUI) such as BRI Syariah, Bank Mega Syariah, Bank Syariah Mandiri, Panin

\footnotetext{
${ }^{20}$ Dwi nur'aini ihsan. "Kualitas Penerapan Good Corporate Governance Pada Bank Umum Syariah Di Indonesia Serta Pengaruhnya Pada Kinerja Keuangan”. Jurnal Ekonomi Islam Volume 7, Nomor 2, September 2016
} 
Syariah Bank, Bank Syariah Bukopin, Bank Victoria Syariah, Bank Muamalat, BCA Syariah, BNI Syariah approved by the Financial Services Authority (OJK) and approved by Bank Indonesia and ratified in the Annual General Meeting of Shareholders (RUPS).

The third point: Members of the Sharia Supervisory Board have at least 3 members. However, the fact that many Islamic banks are members of the Sharia Supervisory Board is less than 3 persons. While the members of 3 people and has been in accordance with AAOIFI standards are Bank BJB Syariah, Bank Mega Syariah Indonesia, Bank Muamalat Indonesia, and Bank Syariah Mandiri. This is enough to prove that there are still many Islamic banks that do not apply the standards issued by AAOIFI. They are only obedient to Bank Indonesia Regulation Number 11/3 / PBI / 2009 concerning Sharia Commercial Bank Article 36 paragraph 1, namely the number of members of DPS at least 2 (two) persons or at most $50 \%$ (fifty percent) of the total members of the Board of Directors. ${ }^{21}$

The fourth point: Whereas the Sharia Supervisory Board's report should state that management has performed its duty and adheres to Sharia principles and that the report should be published in the annual report. The Sharia Supervisory Board report is not presented in the GCG report but it is presented specifically in the annual report so that the author searched for more data to be analyzed by accessing the official website of each Syariah commercial bank to obtain the annual report of each bank. In the AAOIFI standard, there is a provision in the presentation of the content of the Sharia Supervisory Boards: ${ }^{22}$

\section{Shari’a Review}

The explanation of points in the AAOIFI standard in the implementation of GCG in sharia commercial banks will be explained as follows:

The first point:sharia review is to ensure all business activities and bank operations to conform to sharia principles. The analysis results state that sharia review is the duty and responsibility of the Sharia Supervisory Board. The duties and responsibilities of the Sharia Supervisory Board are set forth in Bank Indonesia Regulation Number 11/33 / PBI / 2009 concerning Implementation of Good Corporate Governance for Sharia Commercial Bank and Sharia Business.

The second point: sharia review is done under the scope of the Sharia Supervisory Board. To assist the Sharia Supervisory Board's duties, the management must always provide all information to the Sharia Supervisory Board in relation to the activities and services of Islamic financial institutions that must comply with the principles of sharia. Thus the information Sharia Supervisory Board can play its role and responsibility to conduct review or give opinion. The result of the analysis states that all management of Islamic bank has provided all information to the Sharia Supervisory Board in the

\footnotetext{
${ }^{21}$ Peraturan Bank Indonesia No. 11/3/PBI/2009 Tentang Bank Umum Syariah pasal 36 ayat 1

${ }^{22}$ Accounting, Auditing and Governance Standards for Islamic Financial Institutions (2010). Governance Standard for Islamic Financial Institutions. Manama: AAOIFI
} 
framework of execution of its duties. This is in accordance with Bank Indonesia Regulation Number 11/33 / PBI / 2009 concerning Implementation of Good Corporate Governance for Sharia Commercial Bank and Sharia Business Unit Article 47 paragraph 4 which states that Sharia Supervisory Board has requested data and information related to sharia aspects of the unit work of the Bank in the context of the implementation of its duties. ${ }^{23}$

Third point: the sharia review procedure consists of 3 stages:

1. Planning a review procedure

2. Carrying out procedural reviews

3. Documenting conclusions and reports

The result of the analysis states that the first stage of sharia review is the task of Bank Indonesia which has authority over each sharia bank in Indonesia by stipulating the review procedure as set forth in Bank Indonesia Regulation Number 11/3 / PBI / 2009 concerning Bank General Sharia on Implementation of Good Corporate Governance for Sharia Commercial Bank and Sharia Business Unit article 47. The second and third stages of Sharia Review are also the duties and responsibilities of the Sharia Supervisory Board as described in the GCG report of every sharia commercial bank and also in accordance with Bank Indonesia Regulation Number 11/3 / PBI / 2009 concerning Sharia Commercial Banks on Good Implementation Corporate Governance for Sharia Commercial Bank and Sharia Business Unit Article 47 paragraph 2 and paragraph 3 are: $:^{24}$

\section{Internal Sharia Review}

Internal sharia review is an integral part of IFI's governing organs and operates under the policies established by sharia financial institutions. It must have a statement of purpose, authority, and responsibility (the charter). The following table shows the analysis of GCG reports on the implementation of AAOIFI standard no 3:

The explanation of points in the AAOIFI standard in the implementation of GCG in sharia commercial banks will be explained as follows:

First point: The internal sharia review is conducted by an independent division / department or part of the internal audit department, depending on the size of the Islamic financial institution (IFI). The result of the analysis stated that the division related to Internal Sharia Review at Bank Muamalat is Sharia Compliance which is responsible for assisting Sharia Supervisory Board and as Liaison Officer between Bank Muamalat Indonesia and Sharia Supervisory Board in supervising the aspects of sharia regularly and helping to prepare Supervisory Board oversight report Sharia every semester that must be submitted to the Financial Services Authority. This division is under the director of compliance and risk management.

\footnotetext{
${ }^{23}$ Peraturan Bank Indonesia No. 11/33/PBI/2009 Tentang Pelaksanaan Good Corporate Governance bagi Bank Umum Syariah dan Unit Usaha Syariah pasal 47 ayat 4

${ }^{24}$ Peraturan Bank Indonesia No. 11/33/PBI/2009 Tentang Pelaksanaan Good Corporate Governance bagi Bank Umum Syariah dan Unit Usaha Syariah pasal 47 ayat 2 dan 3
} 
The second point: The Sharia's reviewers should be competent and have an appropriate educational background, which is adept in the jurisprudence of Islamic law (fiqh al-muamalat). The results of the analysis stated that members of Sharia Compliance at Bank Muamalat have sharia competence. This supports the study of Mardian which states that Sharia Compliance Division at Bank Muamalat consists of 4 (four) people and has sharia competence and has clear job description. ${ }^{25}$

Third point: The nature and scope of the internal sharia review is different from the normal audit process. In general, the scope of work consists of examination and evaluation with respect to IFI effectiveness. The result of analysis stated that the scope of Sharia Compliance at Bank Muamalat has been in accordance with AAOIFI standard. This can be seen from the GCG report of Bank Muamalat stating that Sharia Compliance is in charge of assisting the Sharia Supervisory Board and as Liaison Officer between Bank Muamalat Indonesia and Sharia Supervisory Board in supervising the aspects of sharia regularly and helping to prepare supervisory reports of Sharia Supervisory Board every semester shall be submitted to the Financial Services Authority.

\section{Audit and Governance Committee for Islamic Financial Institutions}

The explanation of points in the AAOIFI standard in the implementation of GCG in sharia commercial banks will be explained as follows:

The first point: The Audit and Governance Committee is authorized by the board of directors in the hope of having full communication of the board of directors. The results of the analysis stated that the Audit Committee was established with the objective to support the effectiveness of the implementation of the duties and responsibilities of the Board of Commissioners as well as the implementation of Good Corporate Governance as stipulated in Bank Indonesia Regulation no. 11/33 / PBI / 2009 dated December 7, 2009 on Implementation of Good Corporate Governance for Sharia Commercial Bank and Islamic Business Unit, the Board of Commissioners has established Audit Committee, Risk Monitoring Committee and Remuneration \& Nomination Committee.

The second point: The Audit Committee shall consist of at least three members appointed by the board of directors of non-executive and independent board members who are knowledgeable about the affairs of the institution and all applicable laws and regulations including sufficient understanding of these guidelines, and are required to have an adequate understanding of relevant sharia rules and principles.

Third point: The duties and responsibilities of the Audit Committee are to review internal controls and accounting practices and audit plans. The result of the analysis stated that the duties and responsibilities have also been regulated in Bank Indonesia Regulation

\footnotetext{
${ }^{25}$ Sepky Mardian. Studi Eksplorasi Pengungkapan Penerapan Prinsip Syariah di Bank Syariah. SEBI Islamic Economics \& Finance Journal Vol.04, No.1, Oktober 2011
} 
no. 11/33 / PBI / 2009 concerning Implementation of Good Corporate Governance for Sharia Commercial Bank and Islamic Business Unit article 42 which states that: ${ }^{26}$

1. The Audit Committee as referred to in Article 11 paragraph (1) letter c has the duty and responsibility of at least:

a. evaluate the implementation of internal audit in order to assess the adequacy of internal controls including the adequacy of the financial reporting process; and

b. Coordinate with Public Accounting Firm in the framework of effectiveness of external audit.

2. In order to carry out the tasks referred to in paragraph (1) letter a, the Audit Committee shall at least evaluate:

a. execution of tasks performed by the internal audit function;

b. the implementation of follow-up actions by the Board of Directors on audit findings and / or recommendations from Bank Indonesia supervisory results, internal auditors, Sharia Supervisory Board and / or external auditors, to provide recommendations to the Board of Commissioners.

2. The Audit Committee recommends the appointment of Public Accountant and Public Accountant Office to the Board of Commissioners.

\section{Independence of Shari'a Supervisory Board}

The objective of this standard is to provide guidance for members of the Sharia Supervisory Board of the Sharia Financial Institution (IFI) regarding its independence, monitoring independence and ways to solve independence problems. This guideline requires the Sharia Supervisory Board to regularly assess its relationship with the Islamic Financial Institutions to ensure that the Sharia Supervisory Board is independent.

Members of the Sharia Supervisory Board are prohibited from having financial involvement with clients' affairs and personal and family relationships between the board of directors, management and the Sharia Supervisory Board. Sharia Financial Institutions must have roles and functions of compliance to ensure Sharia compliance so that communication between Sharia Supervisory Board, board of directors, management and auditor is transparent. The analysis of GCG reports that all banks have been implemented in accordance with AAOIFI standards. The analysis can be seen from the GCG report of every sharia commercial bank that has declared the application of bank compliance function. This is in accordance with Bank Indonesia Regulation Number: 13/2 / PBI / 2011 concerning the Implementation of Commercial Bank Compliance Function.

Sharia Financial Institutions must grant shareholder rights, adequate opportunities for dialogue with institutions, the ability to elect board members and the authorized Sharia supervisory board and also ensure fair disclosure of accepted financial and banking practices to enable them to take the right decision regarding their investment in Sharia Financial Institutions. The analysis of GCG reports of all banks have been implemented in accordance

\footnotetext{
${ }^{26}$ Ibid. pasal 36
} 
with AAOIFI standards. The analysis can be seen from the GCG report of every sharia commercial bank that has stated the regular activities of the General Meeting of Shareholders.

Unconditional treatment of fund providers and other stakeholders and related investments and in relation to the provision of adequate financial and non-financial information to enable them to make informed decisions regarding those dealing with institutions. The results of the analysis stated that all sharia banks have met the AAOIFI standard. This can be seen from all sharia commercial banks that always publish their annual reports in their respective websites where all parties can access the website.

Sharia commercial banks should set criteria for appointing boards of directors and management. The results of the analysis states that all sharia banks have met the AAOIFI standard. This analysis can be seen from the GCG report of sharia commercial banks which states that for appointments such as directors and management have passed fit and proper test. This is in accordance with Bank Indonesia Regulation Number: 12/23 / PBI / 2010 About Fit and Proper Test (Fit and Proper Test).

The Board of Directors must play an effective role in leadership, direction and monitoring of its policy implementation. The analysis results stated that all sharia banks have applied AAOIFI standards which can be seen from the GCG report which reveal the duties and responsibilities of the directors in order to achieve its objectives. This is in accordance with Bank Indonesia Regulation Number 11/33 / PBI / 2009 concerning Implementation of Good Corporate Governance for Sharia Commercial Bank and Islamic Business Unit.

Sharia public banks must have audit and governance committees. The result of the analysis stated that all sharia commercial banks have applied AAOIFI standard which can be seen from GCG report which reveal the existence of audit and governance committee. Establishment of audiences and governance committees is an obligation for sharia commercial banks because they are included in Bank Indonesia Regulation Number 11/33 / PBI / 2009 concerning Implementation of Good Corporate Governance for Sharia Commercial Bank and Sharia Business.

The board of directors must actively manage risk management. The result of analysis states that all sharia commercial banks have applied AAOIFI standard. This can be seen from the duties and responsibilities of the directors that the board of directors has established a working unit includes; Internal Audit Unit (SKAI), risk management and compliance departments. The duties and responsibilities of this Board of Directors are in accordance with Bank Indonesia Regulation Number 11/33 / PBI / 2009 concerning Implementation of Good Corporate Governance for Sharia Commercial Bank and Sharia Business Unit article 47.

Sharia Commercial Banks must establish appropriate governance structures to ensure that members of the Board of Directors, members of the Sharia Supervisory Board, management and staff as well as external parties such as external auditors, rating agencies and others with substantial relationships can avoid conflict of interest. The result of analysis stated that all sharia commercial banks have applied AAOIFI standard. This can be seen from any sharia bank that has a policy of handling a conflict of interest. If, in the 
event of the operational activities of the bank, a conflict of interest arises, it has been settled in accordance with the provisions in order to not harm or reduce the Bank's profit. Handling of conflicts of interest has also been included in Bank Indonesia Regulation Number 11/33 / PBI / 2009 concerning Implementation of Good Corporate Governance for Sharia Commercial Bank and Sharia Business Unit.

Sharia commercial banks should establish governance structures that are in accordance with the remuneration policy for boards of directors, sharia supervisory boards and management. The result of analysis states that all sharia commercial banks have applied AAOIFI standard. This can be seen from the GCG report of sharia banks that already have a remuneration committee.

Sharia commercial banks must apply high reporting standards and to maintain transparency standards. The analysis results states that all banks have implemented AAOIFI standards. This can be verified by the structure of the annual GCG report which is in accordance with the reporting standard set forth in Bank Indonesia Regulation Number 11/33 / PBI / 2009 concerning Implementation of Good Corporate Governance for Sharia Commercial Bank and Sharia Business Unit article 62 that: ${ }^{27}$

Every bank must implement a code of ethics. The analysis results stated that all banks have implemented AAOIFI standards. This can be seen in the GCG report where every sharia bank has issued a code of conduct and made it as a guideline in corporate governance.Each bank must have mechanisms to ensure that the principles and standards of governance are adhered to and monitored. The analysis results stated that all banks have implemented AAOIFI standards. This can be seen from the GCG report of sharia banks that have a role in implementing bank compliance function.

\section{Corporate Social Responsibility Conduct and Disclosure for Islamic Financial Institutions}

The objective of Sharia financial institution governance standards is to set standards on the definition of corporate social responsibility for Islamic Financial Institutions, provide mandatory standards and recommendations for implementing CSR in all aspects of the Sharia Financial Institution (IFI) and provide guidance on disclosure of CSR information to IFI stakeholders.

This study aims to find out how the implementation of corporate governance in Islamic banking in Indonesia by using content analysis on the annual report of GCG which has published GCG annual report on each Islamic bank. The results of the analysis shows that the implementation of Good Corporate Governance in Islamic banking in Indonesia has conducted self-assessment periodically by comparing the criteria / indicators on each factor which at least cover 11 (eleven) factors of applying the implementation of Good Corporate Governance.

\footnotetext{
${ }^{27}$ Peraturan Bank Indonesia No. 11/33/PBI/2009 Tentang Pelaksanaan Good Corporate Governance bagi Bank Umum Syariah dan Unit Usaha Syariah pasal 62
} 
In principle, GCG self-assessment is an assessment of the implementation of corporate governance by bank management submitted to the regulator which then sets the end result of the implementation of corporate governance.This is supported by the Regulation of Financial Services Authority (POJK) No.8 / POJK.03 / 2014 and Circular of Financial Services Authority (SEOJK) No.10 / SEOJK.03 / 2014 regarding the Rating of Sharia Commercial Banks and Islamic Business Unit requires all Islamic banking to perform self-assessment of the implementation of Good Corporate Governance periodically in accordance with the period of Bank Rating and if necessary at any time Sharia Commercial Bank is required to update the self-assessment of the implementation of Good Corporate Governance. ${ }^{28}$

Meanwhile, the analysis of the implementation of corporate governance in Islamic banking in Indonesia based on AAOIFI standard shows that the overall Islamic banking in Indonesia has not applied AAOIFI standard optimally. This is because there are still manyIslamic banks that do not have organization related to Internal Sharia Review which function as Liaison Officer between Sharia Supervisory Board and division / business unit in Islamic banking by giving report every 2 months and sharing information about result of opinion of Board of Supervisor Sharia every semester.

This practice is not in line with Pramono's research that confirmed the need for Internal Sharia Review or strengthening Internal Audit staff to participate in the implementation of Sharia supervisory functions and coordinate with the Sharia Supervisory Board. ${ }^{29}$ In addition, this function will complement the ex-post audit function in addition to ex-ante audit, which has not been done maximally in Islamic banks. ${ }^{30}$

\section{CONCLUSION}

Based on the research it can be concluded that:

1. The implementation of Good Corporate Governance in Islamic banking in Indonesia has been running very well especially in Bank BCA Syariah and Bank Syariah Mandiri. This is because in the results of its own assessment (Self-Assessment) on the implementation of Good Corporate Governance in 2016, received a very good predicate, and also surpassed the pioneer of Islamic banking in Indonesia, namely Bank Muamalat on the value obtained by Bank Muamalat that only get good ratings.

2. The implementation of Corporate Governance in Islamic banking in Indonesia has not fully implemented the Corporate Governance standard issued by AAOIFI except Bank Muamalat which has implemented all AAOIFI standards.

\footnotetext{
${ }^{28}$ Surat Edaran Otoritas Jasa Keuangan Nomor 10/SEOJK.03/2014 Tentang Penilaian Tingkat Kesehatan Bank Umum Syariah Dan Unit Usaha Syariah

29 Sigit Pramono (2007). Corporate Governance Mechanism and Internal Shariah Review (ISR) in Islamic Banks: Critical Issues and the Role Gap of Shariah Supervisory Board (SSB). Jurnal Ekonomi Syariah Indonesia , 1 (1), 1-19.

${ }^{30}$ Roszaini Haniffa Hudaib (2004). Disclosure Practices of Islamic Financial Institutions:An Exploratory Study. Accounting, Commerce \& Finance: The Islamic Perspective International Conference V, (pp. 1-30). Brisbane, AUSTRALIA.
} 


\section{SUGGESTION}

1. For Bank BCA Syariah and Bank Syariah Mandiri which have received good predicate in self-assessment, there is a need to continue to maintain and also for other sharia commercial banks to continue practicing the implementation of good corporate governance to become a healthy company and also become part in building Islamic banking industry in Indonesia.

2. For all sharia commercial banks in order to make policies and have special units related to the Internal Shari'a Review. The objective is to assist the duties of the Sharia Supervisory Board and as a Liaison Officer between the Bank and the Sharia Supervisory Board in exercising regular monitoring of sharia aspects and to assist in preparing the supervisory reports of the Sharia Supervisory Board every semester that must be submitted to the Financial Services Authority.

\section{BIBLIOGRAPHY}

Accounting, Auditing and Governance Standards for Islamic Financial Institutions (2010). Governance Standard for Islamic Financial Institutions. Manama: AAOIFI

Azhar Maksum (2005). Tinjauan atas Good Corporate Governance di Indonesia. Medan: Gelanggang Mahasiswa, Kampus USU.

Chapra dan Ahmed (2002). Corporate Governance In Islamic Financial Institutions. Jeddah: Islamic Research dan Islamic Institute, Islamic Development Bank.

Faozan (2013). Implementasi Good Corporate Governance Dan Peran Dewan Pengawas Syariah Di Bank Syariah. Jurnal Ekonomi Islam Vol VII, No. 1

Hussainey, Sherif (2016). "Determinants of compliance with AAOIFI standards by Islamic Banks". International Journal of Islamic and Middle Eastern Finance and Management.

Komite Nasional Kebijakan Governance (2006). Pedoman Umum Good Corporate Governance Indonesia.

Mardian, Sepky (2011). Studi Eksplorasi Pengungkapan Penerapan Prinsip Syariah di Bank Syariah. SEBI Islamic Economics \& Finance Journal Vol.04, No.1.

Moleong (1990). Metodologi Penelitian Kualitatif. Bandung: Remaja Rosdakarya.

Peraturan Otoritas Jasa Keuangan Nomor 30/POJK.05/2014 Bab 2 Pasal 2 Ayat 2

Penjelasan Atas Peraturan Bank Indonesian (PBI) No. 11/33/PBI/2009 Tentang Pelaksanaan Good Corporate Governance (GCG) Bagi Bank Umum Syariah (BUS) dan Unit Usaha Syariah (UUS) pada bagian Umum.

Peraturan Bank Indonesia No. 11/33/PBI/2009 Tentang Pelaksanaan Good Corporate Governance bagi Bank Umum Syariah dan Unit Usaha Syariah

Peraturan Bank Indonesia No. 11/3/PBI/2009 Tentang Bank Umum Syariah pasal 36 ayat 1 
Salinan Surat Edaran Otoritas Jasa Keuangan Nomor 10/SEOJK.03/2014 Tentang Penilaian Tingkat Kesehatan Bank Umum Syariah Dan Unit Usaha Syariah

Subiakto (2004). Analisis Isi Media Metode dan Pemanfaatannya. Dalam B. Bungin (Penyunt.), Metodologi Penelitian Kualitatif. Jakarta: PT RajaGrafindo Persada.

Surat Edaran Bank Indonesia No. 12/13/DPbS tentang Pelaksanaan Good Corporate Governance bagi Bank Umum Syariah dan Unit Usaha Syariah

Surat Edaran Bank Indonesia No. 12/13/DPbs Tentang Pelaksanaan Good Corporate Governance bagi Bank Umum Syariah dan Unit Usaha Syariah.

The Committee on the Financial Aspects of Corporate Governance and Gee and Co. Ltd. 1992

Undang-Undang Republik Indonesia Nomor 21 Tahun 2008 Tentang Perbankan Syariah Pasal 1 Ayat 1

Pramono, S. (2007). Corporate Governance Mechanism and Internal Shariah Review (ISR) in Islamic Banks: Critical Issues and the Role Gap of Shariah Supervisory Board (SSB). Jurnal Ekonomi Syariah Indonesia , 1 (1), 1-19. 